\title{
Dual Mode Diffusion and Sorption of Sodium Chloride in Pre-Cooked Potato (Solanum tuberosum L.)
}

\author{
Hiroko Hashiba ${ }^{1}$, Hiromi Gocho ${ }^{2} \&$ Jiro Komiyama $^{3}$ \\ ${ }^{1}$ Faculty of Health and Nutrition, Tokyo Seiei College, Tokyo, Japan \\ ${ }^{2}$ Department of Human Environmental Science, Jissen Women's University, Tokyo, Japan \\ ${ }^{3}$ Professor Emeritus of Tokyo Institute of Technology, Tokyo, Japan \\ Correspondence: Hiroko Hashiba, Faculty of Health and Nutrition, Tokyo Seiei College, Tokyo 1-4-6, \\ Nishishinkoiwa, Katsushika-ku, Tokyo 124-8530, Japan. Tel: 81-336-920-211. E-mail: hashiba@tsc-05.ac.jp
}

Received: September 16, 2012 Accepted: November 14, 2012 Online Published: January 24, 2012

doi:10.5539/jfr.v2n1p66 URL: http://dx.doi.org/10.5539/jfr.v2n1p66

\begin{abstract}
For cooked potato, we report maximum showing variations of the Fick's diffusion coefficients, $D$, of $\mathrm{NaCl}$ with total salt concentration, $C_{\mathrm{t}}$, in the foodstuff in the temperature range, $30-98^{\circ} \mathrm{C}$. The variations were successfully explained with the dual mode diffusion and sorption theory, which has been successfully applied to the diffusion of $\mathrm{NaCl}$ in cooked Japanese radish, solidified egg white, and pork meats. The original theory (Komiyama \& Iijima, 1974) was revised by changing the definitions of the parameters for the presence of liquid water droplets in the foodstuffs. The sorption isotherms, being found to be almost linear with very slight concave upward curvatures, were explained by invoking the presence of the droplets. Two thermodynamic diffusion coefficients, $D_{\mathrm{T}}(\mathrm{p})$ and $D_{\mathrm{T}}(\mathrm{L})$, of $\mathrm{NaCl}$ of the partition and Langmuir type sorption species, respectively, in the diffusion rate determining region were estimated for the temperature range. The temperature dependences were found to show definite rises in the range of $50-70^{\circ} \mathrm{C}$, suggesting the presence of a transition in the diffusion environment.
\end{abstract}

Keywords: potato, cooking, $\mathrm{NaCl}$, diffusion, dual mode, transition

\section{Nomenclature}

$C_{\mathrm{L}}$ : concentration of the Langmuir species of $\mathrm{NaCl}$ in total potato $\left(\mathrm{mol} \mathrm{kg}^{-1}\right)$

$C_{\mathrm{p}}$ : concentration of the partitioned species of $\mathrm{NaCl}$ in total potato $\left(\mathrm{mol} \mathrm{kg}^{-1}\right)$

$C_{\mathrm{s}}$ : concentration of $\mathrm{NaCl}$ in the outer solution $\left(\mathrm{mol} \mathrm{kg}^{-1}\right)$

$C_{\mathrm{t}}$ : total concentration of $\mathrm{NaCl}$ at a $\eta$ in the potato $\left(\mathrm{mol} \mathrm{kg}^{-1}\right)$

$D$ : Fick's diffusion coefficient $\left(\mathrm{m}^{2} \mathrm{~s}^{-1}\right)$

$D^{*}$ : assumed constant Fick's diffusion coefficient independent of $C_{\mathrm{t}}\left(\mathrm{m}^{2} \mathrm{~s}^{-1}\right)$

$D_{\text {app }}$ : apparent Fick's diffusion coefficient $\left(\mathrm{m}^{2} \mathrm{~s}^{-1}\right)$

$D_{\text {max }}$ : maximum Fick's diffusion coefficient $\left(\mathrm{m}^{2} \mathrm{~s}^{-1}\right)$

$D_{\mathrm{T}}$ : thermodynamic diffusion coefficient $\left(\mathrm{m}^{2} \mathrm{~s}^{-1}\right)$

$D_{\mathrm{T}}(\mathrm{L})$ : thermodynamic diffusion coefficient of the Langmuir species of $\mathrm{NaCl}\left(\mathrm{m}^{2} \mathrm{~s}^{-1}\right)$

$D_{\mathrm{T}}(\mathrm{p})$ : thermodynamic diffusion coefficient of the partitioned species of $\mathrm{NaCl}\left(\mathrm{m}^{2} \mathrm{~s}^{-1}\right)$

$D_{\text {w }}$ : thermodynamic diffusion coefficient of $\mathrm{NaCl}$ in water $\left(\mathrm{m}^{2} \mathrm{~s}^{-1}\right)$

$K: K_{\mathrm{L}} / K_{\mathrm{p}}\left(\mathrm{kg} \mathrm{mol}^{-1}\right)$

$K_{\mathrm{a}}: r K\left(\mathrm{~kg} \mathrm{~mol}^{-1}\right)$

$K_{\mathrm{L}}$ : equilibrium constant of Langmuir mode sorption $\left(\mathrm{kg} \mathrm{mol}^{-1}\right)$

$K_{\mathrm{p}}$ : equilibrium constant of partition mode sorption

$K_{\mathrm{p}}$ : partition coefficient of $\mathrm{NaCl}$ in the water swollen substrate

$r:\left(C_{\mathrm{p}}+C_{\mathrm{L}}\right) / C_{\mathrm{t}}$ 
$S$ : concentration of Langmuir mode sorption site in water swollen substrate $\left(\mathrm{mol} \mathrm{kg}^{-1}\right)$

$S_{\mathrm{a}}: S / r\left(\mathrm{~mol} \mathrm{~kg}^{-1}\right)$

$T$ : temperature $\left({ }^{\circ} \mathrm{C}\right)$

$t$ : diffusion time (s)

$x$ : distance from the surface of potato cross section (m)

\section{Greek symbols}

$\alpha: K S\left(=K_{\mathrm{a}} S_{\mathrm{a}}\right)$

$\beta$ : weight fraction of water swollen substrate in the whole potato

$\eta: \mathrm{x} /(2 \mathrm{t})^{1 / 2}\left(\mathrm{~m} \mathrm{~s}^{-1 / 2}\right)$

$\theta: C_{\mathrm{L}} / S_{\mathrm{a}}$

$\tau$ : tortuosity factor

$\varphi_{\mathrm{p}}$ : volume fraction of polymer component in the $\mathrm{NaCl}$ diffusing region in the water swollen substrate

$\varphi_{\mathrm{w}}: 1-\varphi_{\mathrm{p}}$, volume fraction of water in the $\mathrm{NaCl}$ diffusing region

\section{Introduction}

Until recently, the diffusion behaviors of $\mathrm{NaCl}$ in the cooking process of foodstuffs have been reported only for relatively high $\mathrm{NaCl}$ conditions centering around $5 \%$ or $1 \mathrm{~mol} \mathrm{~kg}^{-1}$ of $\mathrm{NaCl}$ in the seasoning solutions (Djelveh, Gros, \& Bories, 1989). Low saltiness of foodstuffs in home and commercial cooking-seasoning is being currently sought for health concern. Current average dietary salt intake in the United States exceeds $8.6 \mathrm{~g} /$ day, which is considerably higher than the recommended maximum intake level of $6 \mathrm{~g} /$ day (United States Department of Agriculture, 2010). Maximum intake level of $6 \mathrm{~g} /$ day is also recommended in United Kingdom (Food Standards Agency, 2007). In Japan, $9 \mathrm{~g}$ /day for men and $7.5 \mathrm{~g}$ /day for women are recommended (National Institute of Health and Nutrition, 2010).

In our preceding three reports on Japanese radish, solidified egg white, and pork meats, we have discussed the diffusion mechanism of $\mathrm{NaCl}$ below $0.5 \mathrm{~mol} \mathrm{~kg}^{-1}$ of solution (Hashiba, Komiyam, Nakanishi, \& Gocho, 2007; Hashiba, Gocho, \& Komiyama, 2008; Hashiba, Gocho, \& Komiyama, 2009).

The present study reports the diffusion behavior of $\mathrm{NaCl}$ in pre-cooked potato tuber in the temperature range, $30-98^{\circ} \mathrm{C}$. Until now, in spite of the importance of the seasoning of potato in various cooking recipes, relatively little attention has been paid on the cooking-seasoning of this foodstuff. This was so despite of much devotion to elucidate the physicochemical properties of the main component of potato, starch (Mousia, Fahrhat, Blachot, \& Michell, 2000; Roos, 1995; Kalichevsky \& Blanshard, 1992).

On seasoning potato as well as any other foodstuffs, diffusion of $\mathrm{NaCl}$ is the most important subject among those of various seasoning components. With cooked potato which comprises about $80 \%$ water, $17 \%$ carbohydrates and $2 \%$ proteins as the main components, some studies have been devoted for the uptake of $\mathrm{NaCl}$ by the tuber cubes from the salt solutions in an extended temperature range. For example, Liu reported $D_{\text {app }}$ calculated from the uptake by the cube in the range, $50-120^{\circ} \mathrm{C}$ ( $\left.\mathrm{Liu}, 1992\right)$.

The $D_{\text {app }}$ is a parameter which depends on the dimension of the cube (Crank, 1975). However, Liu recognized a kink in the temperature dependence of $D_{\text {app }}$ at around $60^{\circ} \mathrm{C}$. Tamasula and Kozempel (1989) also reported such a change at $60^{\circ} \mathrm{C}$ in the dependence of $D_{\text {app }}$ of $\mathrm{KCl}$.

In accumulated studies on foodstuff seasoning, it is established that the one dimensional diffusion of any diffusant in steady state substrates gives, $D$, defined as the coefficient of the negative concentration gradient to give the flux. If the concentration profile of a diffusant in a substrate is obtained, $D$ at a specified concentration, $C_{\mathrm{t}}$, in the foodstuff can be calculated from the profile (Crank, 1975; Matano, 1932). $D$ can be the measure of the mobility of the diffusant only when $D$ is constant over the concentration range of concern. During the last two decades, however, $D$ values of $\mathrm{NaCl}$ that are explicitly concentration dependent, have been reported for pork meat (Guiheneuf, Gibbs, \& Hall, 1997) and Emmental cheese (Pajonk, Saurel, \& Andrieu, 2003) and recently for Japanese radish, solidified egg white and pork meat at $5-98^{\circ} \mathrm{C}$ by us (Hashiba et al., 2007, 2008, 2009). The dependences reported by us have a common character of each having skewed bell shape variation with a maximum at a $C_{\mathrm{t}}$ value of $\mathrm{NaCl}$ slightly above $0.1 \mathrm{~mol} \mathrm{~kg}^{-1}$. These $D$ values together with $D_{\mathrm{T}}$ values are listed in Table 1 for comparison.

Referring to the scarceness of the studies on diffusion behaviors of $\mathrm{NaCl}$ in carbohydrate foodstuffs, we felt that 
addition of a study on potato is important as a basis to understand the diffusion of $\mathrm{NaCl}$ in many other carbohydrate foodstuffs. In fact, lack of such a study is rather astonishing as compared with those on protein foodstuffs (Rüegg \& Schär, 1985). It may be meaningful to examine whether $D$ values of $\mathrm{NaCl}$ in potato show the same maximum having variations found for the three different kinds of foodstuffs or not.

In our previous three studies, we have applied a dual mode diffusion and sorption theory originally developed for dye diffusion in nylon (Komiyama \& Iijima, 1974). Generally foodstuffs under cooking conditions contain $60-95 \%$ water, which are much more than the water content, $6 \%$ of a polymer substrate like nylon. Thus the original dual mode diffusion theory on nylon should be reexamined when applied to foodstuffs. Referring to the foregoing studies (Hashiba et al., 2007, 2008, 2009), we became aware of the fact that water imbibed in the foodstuffs is partitioned into one swelling the component macromolecular phase and the other one dispersed as liquid water. An extreme example is the radish containing about 95\% water (Hashiba et al., 2007).

In the present study, we show that incorporation of the water droplets imbibed in foodstuffs results in minor change in the definitions of the parameters of the dual mode theory.

Table 1. List of $D$ and $D_{\mathrm{T}}$ 's shown for comparison

\begin{tabular}{|c|c|c|c|c|c|c|}
\hline Foodstuff & $\begin{array}{l}{ }^{T} \\
{ }^{\circ} \mathrm{C}\end{array}$ & $\begin{array}{l}D_{\max } \\
\left(10^{-9} \mathrm{~m}^{2} / \mathrm{s}\right)\end{array}$ & $\begin{array}{l}D_{\min } \\
\left(10^{-9} \mathrm{~m}^{2} / \mathrm{s}\right)\end{array}$ & $\begin{array}{l}D_{\mathrm{T}}(\mathrm{p}) \\
\left(10^{-9} \mathrm{~m}^{2} / \mathrm{s}\right)\end{array}$ & $\begin{array}{l}D_{\mathrm{T}}(\mathrm{L}) \\
\left(10^{-9} \mathrm{~m}^{2} / \mathrm{s}\right)\end{array}$ & Author \\
\hline Pork loin & 21 & $0.55^{* 1}$ & $0.1^{* 1}$ & & & Guiheneuf et al. (1997) \\
\hline \multirow[t]{4}{*}{ Cheese } & 4 & $0.21^{* 1}$ & $0.07^{* 1}$ & & & Pajonk et al. (2003) \\
\hline & 8 & $0.40^{* 1}$ & $0.10^{* 1}$ & & & \\
\hline & 13 & $0.61^{* 1}$ & $0.17^{* 1}$ & & & \\
\hline & 18 & $0.78^{* 1}$ & $0.22^{* 1}$ & & & \\
\hline $\begin{array}{l}\text { Japanese } \\
\text { radish }\end{array}$ & 98 & $5.73^{* 2}$ & $0.66^{* 2}$ & 0.30 & 1.80 & Hashiba et al. (2007) \\
\hline \multirow[t]{4}{*}{ Egg white } & 5 & $0.52^{* 2}$ & $0.28^{* 2}$ & 0.14 & 0.33 & Hashiba et al. (2008) \\
\hline & 30 & $1.23^{* 2}$ & $0.36^{* 2}$ & 0.13 & 0.55 & \\
\hline & 60 & $2.51^{* 2}$ & $0.85^{* 2}$ & 0.36 & 1.60 & \\
\hline & 80 & $6.23^{* 2}$ & $0.96^{* 2}$ & 0.30 & 1.80 & \\
\hline \multirow[t]{3}{*}{ Pork loin } & 5 & $100^{* 2}$ & $0.29^{* 2}$ & 0.12 & 0.40 & Hashiba et al. (2009) \\
\hline & 63 & $1.38^{* 2}$ & $0.48^{* 2}$ & 0.32 & 0.90 & \\
\hline & 98 & $1.66^{* 2}$ & $0.62^{* 2}$ & 0.45 & 1.00 & \\
\hline \multirow[t]{5}{*}{ Potato $^{* 3}$} & 30 & $1.31^{* 2}$ & $0.21^{* 2}$ & 0.06 & 0.54 & Hashiba et al. \\
\hline & 50 & $1.65^{* 2}$ & $0.35^{* 2}$ & 0.11 & 0.76 & (this paper) \\
\hline & 60 & $2.55^{* 2}$ & $0.94^{* 2}$ & 0.38 & 1.55 & \\
\hline & 70 & $3.49^{* 2}$ & $1.04^{* 2}$ & 0.60 & 2.00 & \\
\hline & 98 & $4.35^{* 2}$ & $1.13^{* 2}$ & 0.71 & 2.10 & \\
\hline
\end{tabular}

${ }^{*} 1$ These values are taken from the highest values at the lowest $\mathrm{NaCl}$ concentration measured, which is followed by the monotonical decreases to the lowest values at the highest concentrations.

${ }^{* 2}$ The $D$ values of these foodstuffs show skewed bell shape variations. The highest values were taken at the maxima and the lowest ones were taken at the highest concentrations near $0.45 \mathrm{~mol} / \mathrm{kg} \mathrm{NaCl}$.

${ }^{* 3}$ It was not possible in reported data to estimate the two values for potato because they were single values of $D_{\text {app }}$ for each temperature. 


\section{Model and Theory}

2.1 A Model for Foodstuff Substrates Pertinent to NaCl Diffusion and Reconsideration of the Theoretical Background

For the foodstuff substrates containing $60-95 \%$ water, one may apt to suppose liquid water "channel" penetrating the whole foodstuff body. If this is the case, diffusion of $\mathrm{NaCl}$ should be obstructed by a tortuosity factor, $\tau$, of the liquid water "channel", and hence $D$ is represented as $D_{\mathrm{w}} / \tau$. Thus the $D$ values, which are smaller than $D_{\mathrm{w}}$ by the factor, 2-6 (Cussler, 1997), should be constants, irrespective of $C_{\mathrm{t}}$ but dependent on the foodstuff species. Table 1 shows the ranges observed. However, this has been found not to be the case for the three foodstuffs with the maximum showing variations of $D$ at relatively low concentrations (Hashiba et al., 2007, 2008, 2009). See also the reported variations of $D$ of $\mathrm{NaCl}$ with $C_{\mathrm{t}}$ for L. dorsi and Emmental cheese (Guiheneuf, et al., 1997; Pajonk et al., 2003) shown in Table 1.

Here we present in Figure 1 a model of the organization of foodstuffs relevant to $\mathrm{NaCl}$ diffusion in the four foodstuffs including the present object, potato. More or less depending on the foodstuff species, the organizations should be heterogeneous in a sense that they contain water swollen component regions and dispersed liquid water droplet regions to different degrees. This is most apparent for Japanese radish as already discussed. Solidified egg white and pre-cooked pork meat also show such two phases seen in the SEM photos (Hashiba et al., 2008, 2009).

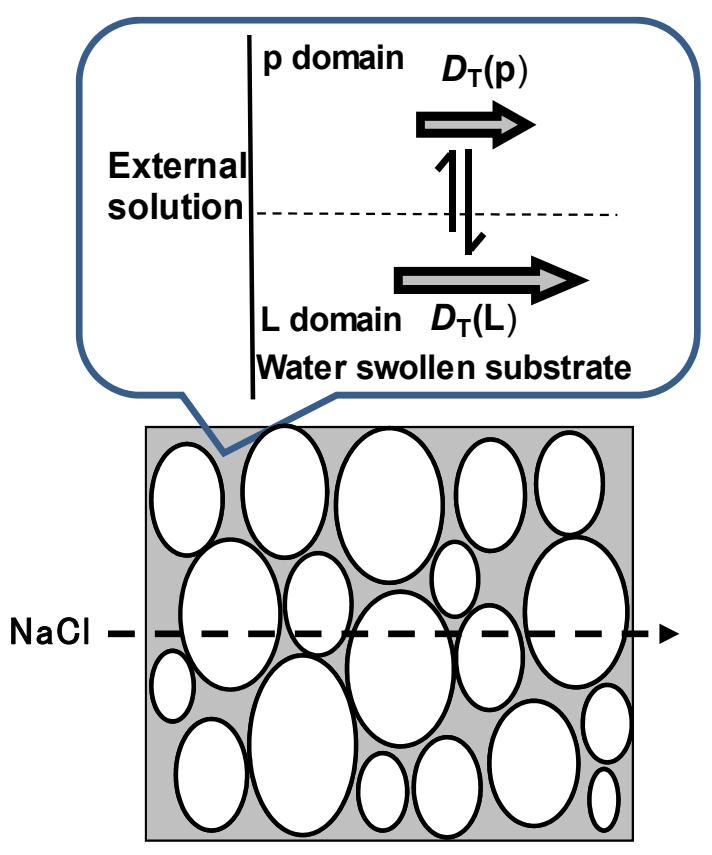

Figure 1. Schematic model of liquid water droplets and water swollen substrate, the latter of which determines the rate of diffusion of $\mathrm{NaCl}$. Oliquid water droplet; water swollen substrate

\subsection{Extension of Original Dual Mode Diffusion and Sorption Theory to Those of NaCl in Foodstuffs Containing Unconnected Liquid Water Droplets}

In the original theory on the dual mode diffusion and sorption of anionic dyes in nylon, all the p species and the $\mathrm{L}$ species absorbed in the substrate was assumed to participate in the rapid equilibrium. This assumption was supported by the fact that the dual mode parameters obtained from the sorption isotherm can explain the variation of $D$ with the dye concentration (Komiyama \& Iijima, 1974; Petropoulos, 1985). Generally in cooked foodstuffs, the total weight of discrete liquid water droplets is considerable as compared with the weight of water in the swollen substrates. Also for $\mathrm{NaCl}$ sorption by the potato, the sorption isotherm is written in the form (Hashiba et al., 2007),

$$
C_{\mathrm{t}}=(1-\beta) C_{\mathrm{s}}+K_{\mathrm{p}} C_{\mathrm{s}}+\frac{K_{\mathrm{L}} S_{\mathrm{a}} C_{\mathrm{s}}}{1+K_{\mathrm{L}} C_{\mathrm{s}}}
$$


The presence of liquid water droplets in foodstuffs makes it necessary to redefine two parameters, $K\left(=K_{\mathrm{L}} / K_{\mathrm{p}}\right)$ and $S$, as $K_{\mathrm{a}}=r K$ and $S_{\mathrm{a}}=S / r$ by introducing $r=\left(C_{\mathrm{p}}+C_{\mathrm{L}}\right) / C_{\mathrm{t}}$. Other parameters which will be used in the later sections, $\alpha=K S\left(=K_{\mathrm{a}} S_{\mathrm{a}}\right), K_{\mathrm{p}}, K_{\mathrm{L}}, D_{\mathrm{T}}(\mathrm{p})$ and $D_{\mathrm{T}}(\mathrm{L})$ are unchanged. Equation (2) in the literature (Komiyama \& Iijima, 1974) gives a relation between $C_{\mathrm{p}}+C_{\mathrm{L}}$ and $\theta$ as,

$$
C_{\mathrm{p}}+C_{\mathrm{L}}=\frac{\theta}{K(1-\theta)}+S \theta
$$

Dividing Equation (2) by $r$, we obtain $C_{\mathrm{t}}$ as

$$
C_{\mathrm{t}}=\frac{C_{\mathrm{p}}+C_{\mathrm{L}}}{r}=\frac{\theta}{r K(1-\theta)}+\frac{S}{r} \theta=\frac{\theta}{K_{\mathrm{a}}(1-\theta)}+S_{\mathrm{a}} \theta
$$

Thus, $K$ and $S$ in our former three reports should be read as $K_{\mathrm{a}}$ and $S_{\mathrm{a}}$ (Hashiba et al., 2007, 2008, 2009). In principle, $r$ depends on $C_{\mathrm{t}}$. However, with the four foodstuffs, Japanese radish, egg white, pork meat, and potato in this paper, it has been experimentally confirmed that the sorption isotherms observed for $C_{\mathrm{t}}$ below $0.513 \mathrm{~mol}$ $\mathrm{kg}^{-1}$ are very close to straight lines with ca. $2 \%$ deviations by concave upward curvatures. This is a result of the very small $\mathrm{L}$ type sorption parameters, $K_{\mathrm{L}}$, probably equal or less than 10 , a characteristic of the Langmuir type sorption in foodstuff substrates. These fortuitous conditions in determining the sorption isotherms have made it allowable to assume constant $r$ for the $C_{\mathrm{t}}$ range in all of the four studies. Thus, the explicit appearance of the $\mathrm{L}$ mode in the dependences of $D$ on $C_{\mathrm{t}}$, and the apparent disappearance of the mode in sorption isotherms are reconciled.

In spite of the above definitions of $K_{\mathrm{a}}$ and $S_{\mathrm{a}}$, the key Equation (4) to account for the variation of $D$ with $\theta$ is unchanged because $K_{\mathrm{a}} S_{\mathrm{a}}$ reduces to $K S=\alpha$, which does not contain $r$.

$$
D\left(C_{\mathrm{t}}\right)=D_{\mathrm{p}}+D_{\mathrm{L}}=D_{\mathrm{T}}(\mathrm{p}) \frac{1}{\alpha(1-\theta)^{2}+1}+D_{\mathrm{T}}(\mathrm{L}) \frac{\alpha(1-\theta)}{\alpha(1-\theta)^{2}+1}
$$

This equation indicates that $D$ is represented as the sum of the products of mobility factors, $D_{\mathrm{T}}$ 's, and the equilibrium factors comprising $\alpha$ and $\theta$. The maxima which will be shown also for the potato in Figure 4 of $D$ vs. $C_{\mathrm{t}}$ plots, result from the variations of the equilibrium factors for $\mathrm{L}$ species. In another words, without $\mathrm{L}$ mode sorption and diffusion in fast equilibrium with $\mathrm{p}$ mode species, no maximum showing variation of $D$ should not be observed. Such an equilibrium mechanism plays crucially important role in determining $D$ variations in foodstuffs. A foodstuff model depicted in Figure 1 may illustrate the organization of the regions which reasonably explains the dual mode diffusion and sorption taking place in so far mentioned foodstuffs.

\subsection{Factors That Determine $D_{T}(p)$ and $D_{T}(L)$}

Another important implication of Equation (4) is that the appearance of a maximum in the variation of $D$ with $C_{\mathrm{t}}$ means that $D_{\mathrm{T}}(\mathrm{L})$ is comparable or larger than $D_{\mathrm{T}}(\mathrm{p})$, i.e., the Langmuir species of $\mathrm{NaCl}$ diffuses with almost the same speed or faster than the partition species. Why so? To assign $\mathrm{L}$ and $\mathrm{p}$ regions, we refer to the dual mode sorption of 1:1 salt in amphoteric ion exchange resins reported in three studies (Michaeli \& Bejerano, 1969; Okada \& Patilt, 1998; Sinn, Dimola, Huin, Sel, \& Antonietti, 2006). In the resins which contain water by about $50 \%$, the one dimensional mobilities of the ions absorbed in dual mode must be determined by the obstructions of the resin composing immobile macromolecular chains. Equation (5) gives the reductions of $D_{\mathrm{T}}$ 's according to $\varphi_{\mathrm{p}}$ 's in the regions (Mackie \& Mears, 1955).

$$
\frac{D_{\mathrm{T}}}{D_{\mathrm{W}}}=\left(\frac{1-\varphi_{\mathrm{p}}}{1+\varphi_{\mathrm{p}}}\right)^{2}
$$

We assume that the $\mathrm{p}$ and $\mathrm{L}$ regions contain different macromolecular fractions by assigning charged region in various foodstuffs to $L$ type region and uncharged one to $\mathrm{p}$ type region. Charged $\mathrm{L}$ type region naturally contains more water than uncharged $\mathrm{p}$ type region. This assumption is in reasonable correspondence to the faster diffusion of $\mathrm{L}$ species than $\mathrm{p}$ species of $\mathrm{NaCl}$. The curve for skewed bell shape variations of $D$ with $C_{\mathrm{t}}$ observed for cooked potato was computer-fitted by the least squares method with $D_{\mathrm{T}}(\mathrm{L}), D_{\mathrm{T}}(\mathrm{p}), \alpha$, and $S_{\mathrm{a}}$.

\section{Materials and Methods}

\subsection{Preparation of Pre-Cooked Potato}

Soggy Cynthia (Germicopa, S. A., France) potato tubers, which were in ellipsoid form with around $90 \mathrm{~mm}$ and $60 \mathrm{~mm}$ as the longitudinal and latitudinal diameters, respectively, were purchased as a $5 \mathrm{~kg}$ lot from Koganezaki 
farm in Hirosaki City, Aomori prefecture, Japan in August, 2009. The tubers were stored at $4^{\circ} \mathrm{C}$ and were kept wrapped overnight at room temperature before use. From the central portion, cylinders with $50 \mathrm{~mm}$ in diameter and $60 \mathrm{~mm}$ long were cut and were steam heated at $98^{\circ} \mathrm{C}$ for 40 minutes. Components of raw and the pre-cooked potato obtained by duplicate chemical analyses are shown in Table 2. The measurements of the concentration profile of $\mathrm{NaCl}$ and the sorption isotherms were performed with the samples cut out from the pre-cooked potato.

\subsection{SEM of Raw and Pre-Cooked Potatoes}

The samples of the raw and pre-cooked potato tubers were served for microstructure examination with a low vacuum pressure SEM, JSM-6380, by the courtesy of Jeol Co. Ltd., Tokyo, Japan. The samples were cut perpendicular to the tuber axis using a razor blade to produce the transverse section. The specimens were photographed on the cool stage at $-10^{\circ} \mathrm{C}$ and a magnification of $300 \mathrm{x}$ at an accelerating voltage of $15 \mathrm{KV}$.

\subsection{Chemical Analyses}

Duplicate measurements of moisture, protein, lipid, and ash contents of raw and pre-cooked potatoes were performed by Japan Food Research Laboratories according to Standard Tables of Food Composition in Japan (Resources Council of the Science and Technology Agency (RCSTA), Japan, 1982). Table 2 shows the results.

\subsection{Measurement of One-Dimensional Concentration Profile of $\mathrm{NaCl}$ in Pre-Cooked Potato}

The profiles of $\mathrm{NaCl}$ in the pre-cooked potatoes were measured at $30,50,60,70$, and $98^{\circ} \mathrm{C}$ by the FRITRUC method described in a previous report (Hashiba et al., 2007). The cylinder with $36 \mathrm{~mm}$ in diameter and $50 \mathrm{~mm}$ long cut out from the pre-cooked potato, was covered with a thin rubber casing and was immersed in $3.00 \%$ $\left(0.513 \mathrm{~mol} \mathrm{~kg}^{-1}\right) \mathrm{NaCl}$ solutions at the temperatures. $\mathrm{NaCl}$ was allowed to diffuse one-dimensionally into the cylinder from the one open cross-section. As seen in Figure 3, the profiles plotted against the reduced parameter, $\eta=x /(2 t)^{1 / 2}$, for two periods at respective temperatures agreed quite well.

\subsection{Determination of $\mathrm{D}$ of $\mathrm{NaCl}$}

$D$ values at respective $C_{\mathrm{t}}$ in the potato cylinder were obtained by applying Matano's method (Crank, 1975; Matano, 1932) to the concentration profiles. Details of the calculation method were described in a previous report (Hashiba et al., 2007).

\subsection{Measurement of Sorption Isotherm of $\mathrm{NaCl}$}

Equilibrium concentrations of $\mathrm{NaCl}$ in the pre-cooked potato were measured at $30,50,60,70$, and $98^{\circ} \mathrm{C}$ for the potato discs with $32 \mathrm{~mm}$ diameter and $2 \mathrm{~mm}$ in thickness immersed for $2 \mathrm{hrs}$ in $2 \mathrm{~L}$ solutions containing up to $0.513 \mathrm{~mol} \mathrm{~kg}^{-1} \mathrm{NaCl}$. Figure 6 shows the sorption isotherms. The measurements were repeated at least two times for each $C_{\mathrm{s}}$.

\subsection{Statistical Analysis}

Statistical analyses of the obtained data were carried out by using the statistical package (Excel Toukei 2010 for Windows, StatSoft, Tokyo, Japan). T-test was applied to the data. Differences were considered at $\mathrm{p}<0.05$.

\section{Results and Discussion}

\subsection{SEM Photos of Raw and Pre-Cooked Potatoes}

Natural SEM photos of the raw and pre-cooked potatoes are shown in Figure 2a and b, respectively. In Figure 2a, intact starch granules of different sizes are seen in the raw potato cells. After the steaming, the granules and cell walls are seen to be merged to about 1.3 times large to the area of the cell size. The merged grains are seen to have some texture on the surface. It is apparent that the grains are water swollen to certain extents. 

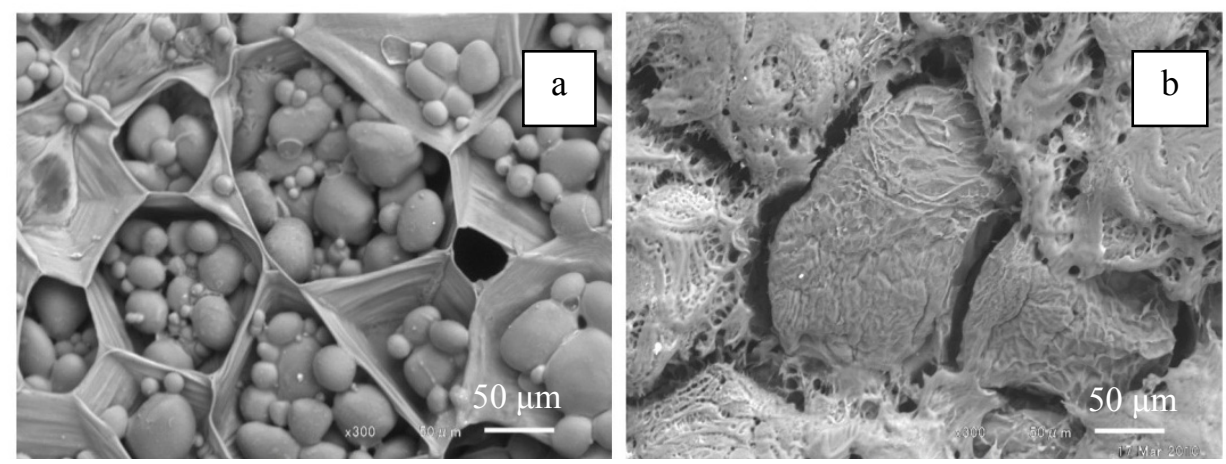

Figure 2. Natural SEM photos of the cross sections of the potato. (a) raw potato and (b) pre-cooked potato at $98^{\circ} \mathrm{C}$ for $40 \mathrm{~min}$. Magnification at $\times 300$

\subsection{Analyses of the Potato Components}

The analytical data shown in Table 2 for the components of the raw potato are in agreements within $5 \%$ with the values for potato listed in Standard Tables of Food Composition in Japan (RCSTA, Japan, 2005). The water content, $80 \%$ of the pre-cooked potato is slightly higher than that of the raw potato. The protein and carbohydrate contents of the pre-cooked potato become slightly lowered by the pre-cooking. In the measurements of $D$ at temperatures higher than $60^{\circ} \mathrm{C}$, it was found that $S_{\text {a }}$ presumed to be a measure corresponding to charged substances in the substrate, becomes small with the temperature. With solidified egg white, $S_{\mathrm{a}}$ values at $5-80^{\circ} \mathrm{C}$ were found to be unchanged (Hashiba et al., 2008). While with pork meat, the value became small with the cooking temperature, which can be related with the charged protein dissolution conventionally observed on making of soup stock by cooking (Hashiba et al., 2009). These facts being referred to, slight lowering of the two components may be related with the reduction of $S_{\mathrm{a}}$ of the potato at high temperatures, due to the dissolution of the charged protein components and/or the pectin at high temperatures.

Table 2. Components of potato

\begin{tabular}{llllll}
\hline Potato & $\begin{array}{l}\text { Moisture } \\
(\mathrm{g} / 100 \mathrm{~g})\end{array}$ & $\begin{array}{l}\text { Protein } \\
(\mathrm{g} / 100 \mathrm{~g})\end{array}$ & $\begin{array}{l}\text { Lipid } \\
(\mathrm{g} / 100 \mathrm{~g})\end{array}$ & $\begin{array}{l}\text { Ash } \\
(\mathrm{g} / 100 \mathrm{~g})\end{array}$ & $\begin{array}{l}\text { Carbohydrate } \\
(\mathrm{g} / 100 \mathrm{~g})\end{array}$ \\
\hline Raw & $79.7 \pm 0.11^{\mathrm{a}}$ & $1.68 \pm 0.04$ & $0.13 \pm 0.01$ & $0.67 \pm 0.01$ & $17.8 \pm 0.15^{\mathrm{a}}$ \\
Pre-cooked & $80.5 \pm 0.04^{\mathrm{b}}$ & $1.55 \pm 0.02$ & $0.12 \pm 0.01$ & $0.71 \pm 0.01$ & $17.1 \pm 0.06^{\mathrm{b}}$ \\
\hline
\end{tabular}

Data was obtained by Japan Food Research Laboratories. Values are the mean \pm S.D. of duplicate measurements. Different letters within a column indicate significant difference at $\mathrm{p}<0.05$.

\subsection{Variations of $D$ with $C_{t}$}

Figure 3 shows the concentration profiles of $\mathrm{NaCl}$ in the potato measured at $30-98^{\circ} \mathrm{C} . D$ values estimated from these profiles are shown against $C_{\mathrm{t}}$ in Figure 4. Like Japanese radish, solidified egg white, and pork meats, $D$ values in the potato show variations in skewed bell shapes with distinct maxima. Theoretical curves shown in Figure 4 were obtained with parameters, $\alpha, S_{\mathrm{a}}, K_{\mathrm{a}}\left(=\alpha / S_{\mathrm{a}}\right), D_{\mathrm{T}}(\mathrm{p})$, and $D_{\mathrm{T}}(\mathrm{L})$ listed in Table 3 . It is seen that the variations of $D$ with $C_{\mathrm{t}}$ at respective temperature are reasonably reproduced in terms of Equation (4). Refer to the iteration method for the curve fitting (Hashiba et al., 2009). 

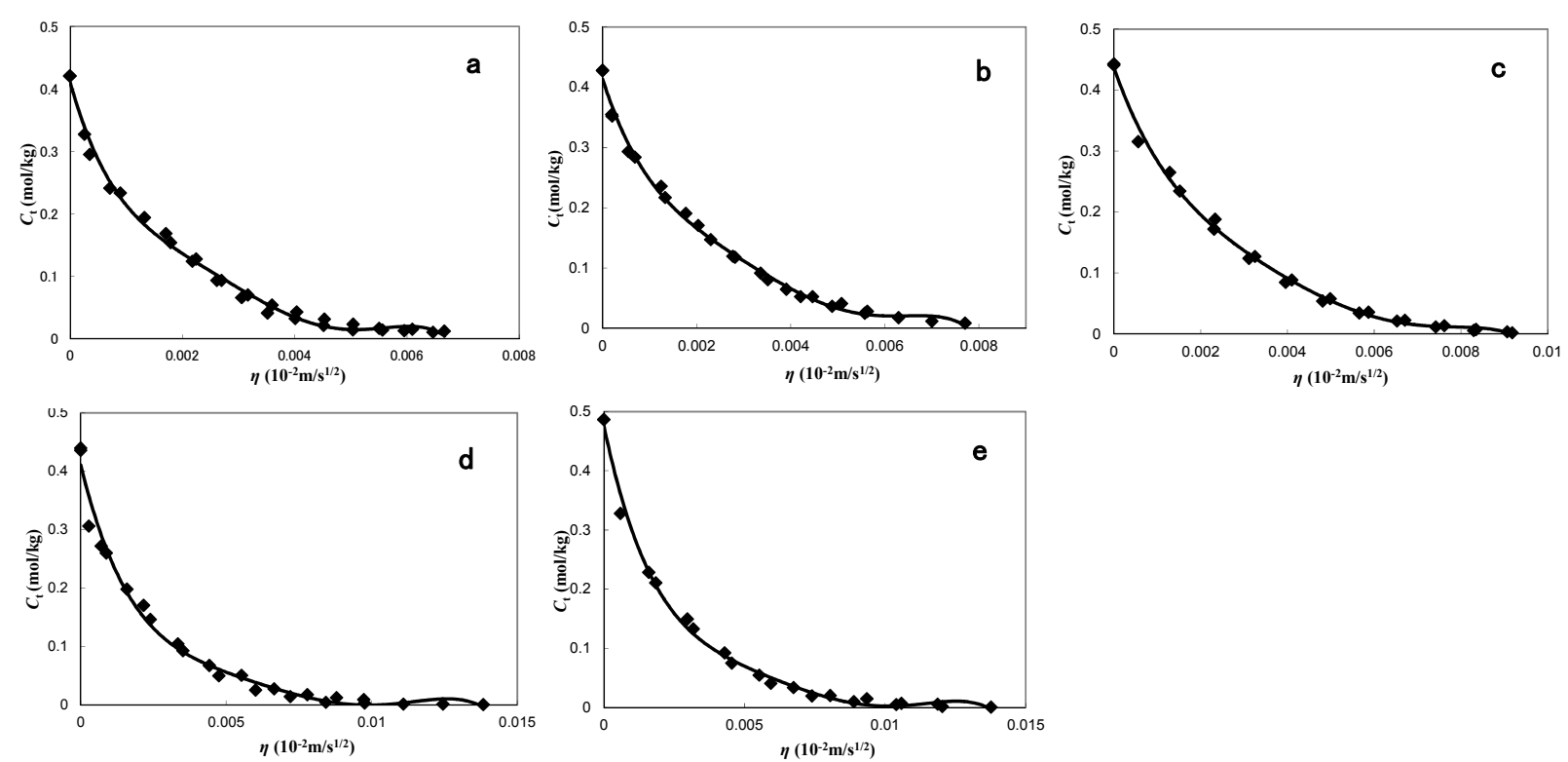

Figure 3. Concentration profiles of $\mathrm{NaCl}$ in the potato at (a) $30^{\circ} \mathrm{C}$, (b) $50^{\circ} \mathrm{C}$, (c) $60^{\circ} \mathrm{C}$, (d) $70^{\circ} \mathrm{C}$, and (e) $98^{\circ} \mathrm{C}$.

$\checkmark$ experimental value; $\longrightarrow$ line obtained by quintic approximation
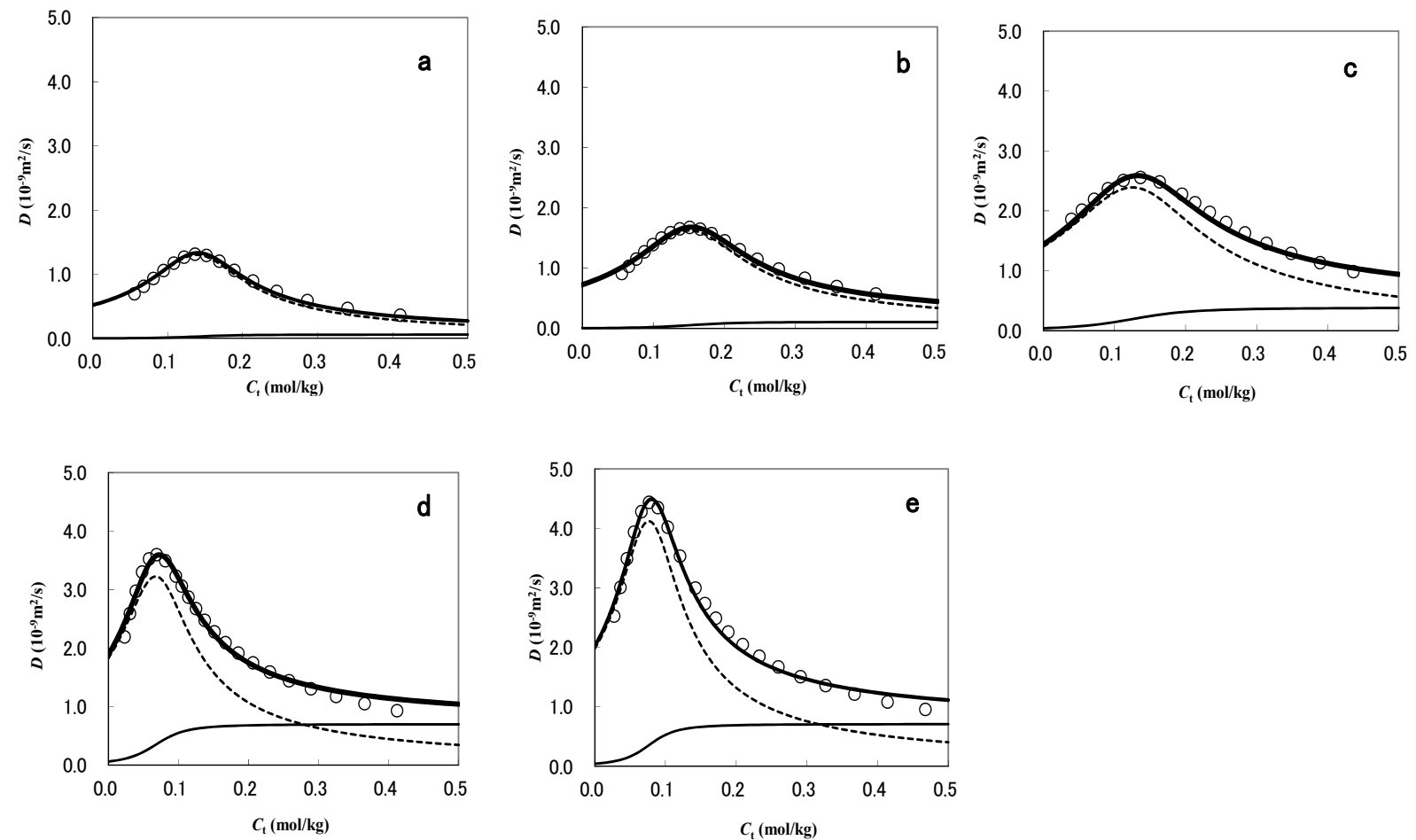

Figure 4. Dependences on $C_{\mathrm{t}}$ of $\mathrm{D}$ of $\mathrm{NaCl}$ in the potato at (a) $30^{\circ} \mathrm{C}$, (b) $50^{\circ} \mathrm{C}$, (c) $60^{\circ} \mathrm{C}$, (d) $70^{\circ} \mathrm{C}$ and (e) $98^{\circ} \mathrm{C}$. Oexperimental value; theoretical $D ; \longrightarrow$ theoretical $D_{\mathrm{p}}$; - - - - - - theoretical $D_{\mathrm{L}}$

A discussion may be made on an assumed inclusion of the constant value, $D^{*}$, independent of $C_{\mathrm{t}}$, which might result from connected water droplets in the potato. If this were the case, the dual mode theory should be applied to the values of (observed variations of $D$ minus constant $D^{*}$, where $D^{*}$ might be included in $D$ ). With assumed $10 \%$ of $D^{*}$ at $C_{\mathrm{t}} \rightarrow 0$ subtracted as such a contribution, each variation of $D$ data was found to give the larger $D_{\max } / D_{\mathrm{T}}(\mathrm{L})$ ratio. This leads to the larger $\alpha$ and results in inward deviations of the calculated curves from the 
observed bell shape points. Thus, no contribution of $D^{*}$ seems to be included in the variations of $D$.

The dependence of $\alpha$ on temperature shows a variation with a minimum at $60^{\circ} \mathrm{C}$. Since $\alpha$ is a product of $S_{\mathrm{a}}$ and $K_{\mathrm{a}}$, we must refer to their numerical values in the third and fourth columns of Table 3. It is seen that $S_{\mathrm{a}}$ becomes small with temperature and $K_{\mathrm{a}}$ assumes a minimum at $60^{\circ} \mathrm{C}$. Such variations are the origins of the appearance of the minimum of $\alpha$ value. For the decrease of $S_{\mathrm{a}}$ at high temperatures, we have discussed the origin in 4.2 section.

$D_{\mathrm{T}}(\mathrm{p})$ and $D_{\mathrm{T}}(\mathrm{L})$ values in Table 3 indicate that $D_{\mathrm{T}}(\mathrm{p})$ values are 1/3 1/9 of those of $D_{\mathrm{T}}(\mathrm{L})$. Such a difference in the magnitudes has also been found in the former studies for Japanese radish, solidified egg white, and pork meats. In 4.4 section, we ascribe the reason to the difference in the fractions of macromolecular entities or inversely, those of water in $\mathrm{p}$ and $\mathrm{L}$ regions.

Table 3. Parameters for dual mode diffusion of $\mathrm{NaCl}$ in potato

\begin{tabular}{llllll}
\hline $\begin{array}{l}T \\
\left({ }^{\circ} \mathrm{C}\right)\end{array}$ & $\alpha$ & $\begin{array}{l}S_{\mathrm{a}} \\
(\mathrm{g} / 100 \mathrm{~g})\end{array}$ & $\begin{array}{l}K_{\mathrm{a}} \\
(\mathrm{kg} / \mathrm{mol})\end{array}$ & $\begin{array}{l}D_{\mathrm{T}}(\mathrm{p}) \\
\left(10^{-9} \mathrm{~m}^{2} / \mathrm{s}\right)\end{array}$ & $\begin{array}{l}D_{\mathrm{T}}(\mathrm{L}) \\
\left(10^{-9} \mathrm{~m}^{2} / \mathrm{s}\right)\end{array}$ \\
\hline 30 & $23.3 \pm 0.92^{\mathrm{a}}$ & $0.145 \pm 0.001^{\mathrm{a}}$ & $161 \pm 4.8^{\mathrm{a}}$ & $0.06 \pm 0.01^{\mathrm{a}}$ & $0.54 \pm 0.01^{\mathrm{a}}$ \\
50 & $18.3 \pm 0.35^{\mathrm{b}}$ & $0.160 \pm 0.001^{\mathrm{b}}$ & $114 \pm 3.2^{\mathrm{bc}}$ & $0.11 \pm 0.01^{\mathrm{b}}$ & $0.76 \pm 0.01^{\mathrm{a}}$ \\
60 & $9.5 \pm 0.14^{\mathrm{c}}$ & $0.140 \pm 0.004^{\mathrm{a}}$ & $68 \pm 2.6^{\mathrm{d}}$ & $0.38 \pm 002^{\mathrm{c}}$ & $1.55 \pm 0.01^{\mathrm{b}}$ \\
70 & $10.7 \pm 0.85^{\mathrm{d}}$ & $0.075 \pm 0.001^{\mathrm{c}}$ & $143 \pm 8.9^{\mathrm{b}}$ & $0.60 \pm 0.07^{\mathrm{d}}$ & $2.00 \pm 0.07^{\mathrm{c}}$ \\
98 & $15.4 \pm 1.13^{\mathrm{b}}$ & $0.082 \pm 0.001^{\mathrm{c}}$ & $188 \pm 18^{\mathrm{ac}}$ & $0.71 \pm 0.01^{\mathrm{d}}$ & $2.10 \pm 0.07^{\mathrm{c}}$
\end{tabular}

Values are the mean \pm S.D. of duplicate measurements. Different letters within a column indicate significant difference at $\mathrm{p}<0.05$.

\subsection{The Origin of Smaller $D_{T}(p)$ Values than $D_{T}(L)$ Ones}

In terms of Mackie and Mears theory, $D_{\mathrm{T}}(\mathrm{p})$ values smaller than $D_{\mathrm{T}}(\mathrm{L})$ ones are ascribed to the smaller fraction of water in $\mathrm{p}$ region than in $\mathrm{L}$ region. This interpretation is compatible with the presumption that $\mathrm{p}$ region is in the domain close to uncharged macromolecules and $\mathrm{L}$ region is that close to charged macromolecules contained in the potato substrate. Table 4 shows the water fractions, $\varphi_{\mathrm{w}}$ values of $\mathrm{p}$ and $\mathrm{L}$ regions calculated from $D_{\mathrm{T}}(\mathrm{p})$, $D_{\mathrm{T}}(\mathrm{L})$, and $D_{\mathrm{w}}$. It is found that $\mathrm{p}$ regions contain about $45 \%$ water while $\mathrm{L}$ regions contain about $76 \%$ water on averages. Table 5 compares these $\varphi_{\mathrm{w}}$ values of the two regions at the highest temperatures measured for the four foodstuffs (Hashiba et al., 2007; 2008; 2009). Intuitively speaking on the water swollen foodstuffs containing large fractions of liquid water, these values may be acceptable as giving not too hard and not too soft for the relevant portions in cooked foodstuffs.

Table 4. Water fractions of the two regions for potato

\begin{tabular}{llllll}
\hline $\begin{array}{l}T \\
\left({ }^{\circ} \mathrm{C}\right)\end{array}$ & $\begin{array}{l}D_{\mathrm{W}} \\
\left(10^{-9} \mathrm{~m}^{2} / \mathrm{s}\right)\end{array}$ & $\varphi_{\mathrm{p}}(\mathrm{p})$ & $\varphi_{\mathrm{p}}(\mathrm{L})$ & $\varphi_{\mathrm{w}}(\mathrm{p})$ & $\varphi_{\mathrm{w}}(\mathrm{L})$ \\
\hline 30 & 1.82 & 0.69 & 0.29 & 0.31 & 0.71 \\
50 & 2.75 & 0.67 & 0.31 & 0.33 & 0.69 \\
60 & 3.29 & 0.49 & 0.19 & 0.51 & 0.81 \\
70 & 3.87 & 0.43 & 0.16 & 0.57 & 0.84 \\
98 & 5.62 & 0.48 & 0.24 & 0.52 & 0.76 \\
\hline
\end{tabular}

$\varphi_{\mathrm{p}}$; volume fraction of polymer component in the water swollen substrate. $\varphi_{\mathrm{w}}=1-\varphi_{\mathrm{p}}$; volume fraction of water in the water swollen substrate. 
Table 5. Water fractions of the two regions for the four foodstuffs

\begin{tabular}{lllllllll}
\hline Foodstuff & $T$ & $D_{\mathrm{T}}(\mathrm{p})$ & $D_{\mathrm{T}}(\mathrm{L})$ & $D_{\mathrm{W}}$ & $\varphi_{\mathrm{p}}(\mathrm{p})$ & $\varphi_{\mathrm{p}}(\mathrm{L})$ & $\varphi_{\mathrm{w}}(\mathrm{p})$ & $\varphi_{\mathrm{w}}(\mathrm{L})$ \\
& $\left({ }^{\circ} \mathrm{C}\right)$ & $\left(10^{-9} \mathrm{~m}^{2} / \mathrm{s}\right)$ & $\left(10^{-9} \mathrm{~m}^{2} / \mathrm{s}\right)$ & $\left(10^{-9} \mathrm{~m}^{2} / \mathrm{s}\right)$ & & & & \\
\hline Japanese radish & 98 & 0.30 & 1.80 & 5.62 & 0.62 & 0.28 & 0.38 & 0.72 \\
Egg white & 80 & 0.30 & 1.60 & 4.26 & 0.58 & 0.24 & 0.42 & 0.76 \\
Pork loin & 98 & 0.45 & 1.00 & 5.62 & 0.56 & 0.41 & 0.44 & 0.59 \\
Potato & 98 & 0.71 & 2.10 & 5.62 & 0.48 & 0.24 & 0.52 & 0.76 \\
\hline
\end{tabular}

$\varphi_{\mathrm{p}}$; volume fraction of polymer component in the water swollen substrate. $\varphi_{\mathrm{w}}=1-\varphi_{\mathrm{p}}$; volume fraction of water in the water swollen substrate.

\section{5 "Transition" of $\mathrm{NaCl}$ Diffusing Regions in the Potato}

Table 3 shows distinct rises of $D_{\mathrm{T}}(\mathrm{p})$, and $D_{\mathrm{T}}(\mathrm{L})$ values between 50 and $70^{\circ} \mathrm{C}$. Since the present measurements of $D$ were performed for the pre-cooked potato of which starch had once been gelatinized, these rises are ascribed to some kinds of transition of $\mathrm{p}$ and $\mathrm{L}$ regions for $\mathrm{NaCl}$ diffusion accompanied by the enhancements of the equilibrium water fractions at the temperature range. However, one can exclude the participation of the 'transition' of the starch contained in the potato, which has been established as the relatively slow retrogradation of cooked potato (Karlsson \& Eliasson, 2003). The transition has been extensively studied with the separated starches from various foodstuffs. The starting temperature of the retrogradation of potato starch-water system was assigned to $35-40^{\circ} \mathrm{C}$ (Karlsson \& Eliasson, 2003; Fredriksson, Silverio, Anderson, Eliasson, \& Aman, 1998). Since a difference of $10-15^{\circ} \mathrm{C}$ is observed between the starting temperature of the transitions of the $\mathrm{NaCl}$ diffusing regions and those of the retrogradation, former regions may be reasonably ascribed to some components other than starch contained in the potato. Proteins like patatin and pectin contained in the cooked potato may be most suspected ones for those providing the diffusion areas for $\mathrm{NaCl}$. In addition, concomitant transitions of $\mathrm{p}$ and $\mathrm{L}$ regions are found in the temperature range, $50-70^{\circ} \mathrm{C}$. This seems to imply that the two regions are very close to each other, probably on a single macromolecular chain.

\subsection{The Temperature Dependences of the $D_{T}$ 's in the Potato Compared with the Other Foodstuffs}

Figure $5 \mathrm{a}, \mathrm{b}$, and c compares the temperature dependences of $D_{\mathrm{T}}(\mathrm{p})$ and $D_{\mathrm{T}}(\mathrm{L})$ values of $\mathrm{NaCl}$ in the potato, pork meat pre-cooked at immersing temperatures, and solidified egg white pre-cooked at $80^{\circ} \mathrm{C}$ (Hashiba et al., 2008; 2009). $D_{\mathrm{w}}$ of $\mathrm{NaCl}$ at the corresponding temperature range (Robinson \& Stokes, 1959) is also plotted in the figure. Compared with the dependence of $D_{w}, D_{\mathrm{T}}(\mathrm{p})$ and $D_{\mathrm{T}}(\mathrm{L})$ in the potato over $70^{\circ} \mathrm{C}$ are found not to increase with temperature. The same kind leveling off of $D_{\mathrm{T}}$ values are found in Figure $5 \mathrm{~b}$ for the pork meat. These two observations may indicate that the elution of the part of the components soluble in water that provide the $\mathrm{p}$ and $\mathrm{L}$ regions, takes place increasingly at high temperatures. Since the elution probably occurs from more hydrophilic components, $S_{\mathrm{a}}$ decreases with the remaining of less hydrophilic components. As a reference, $D_{\mathrm{T}}(\mathrm{L})$ in solidified egg white shows a beginning of the transition at $30^{\circ} \mathrm{C}$ and the increase of $D_{\mathrm{T}}(\mathrm{L})$ continues up to $80^{\circ} \mathrm{C}$. For the egg white, $S_{\mathrm{a}}$ values were found to be constant in the temperature range, 5 to $80^{\circ} \mathrm{C}$ (Hashiba et al., 2008). Such constancy seems to imply no elution of the soluble moieties in the egg white at the temperature range. 

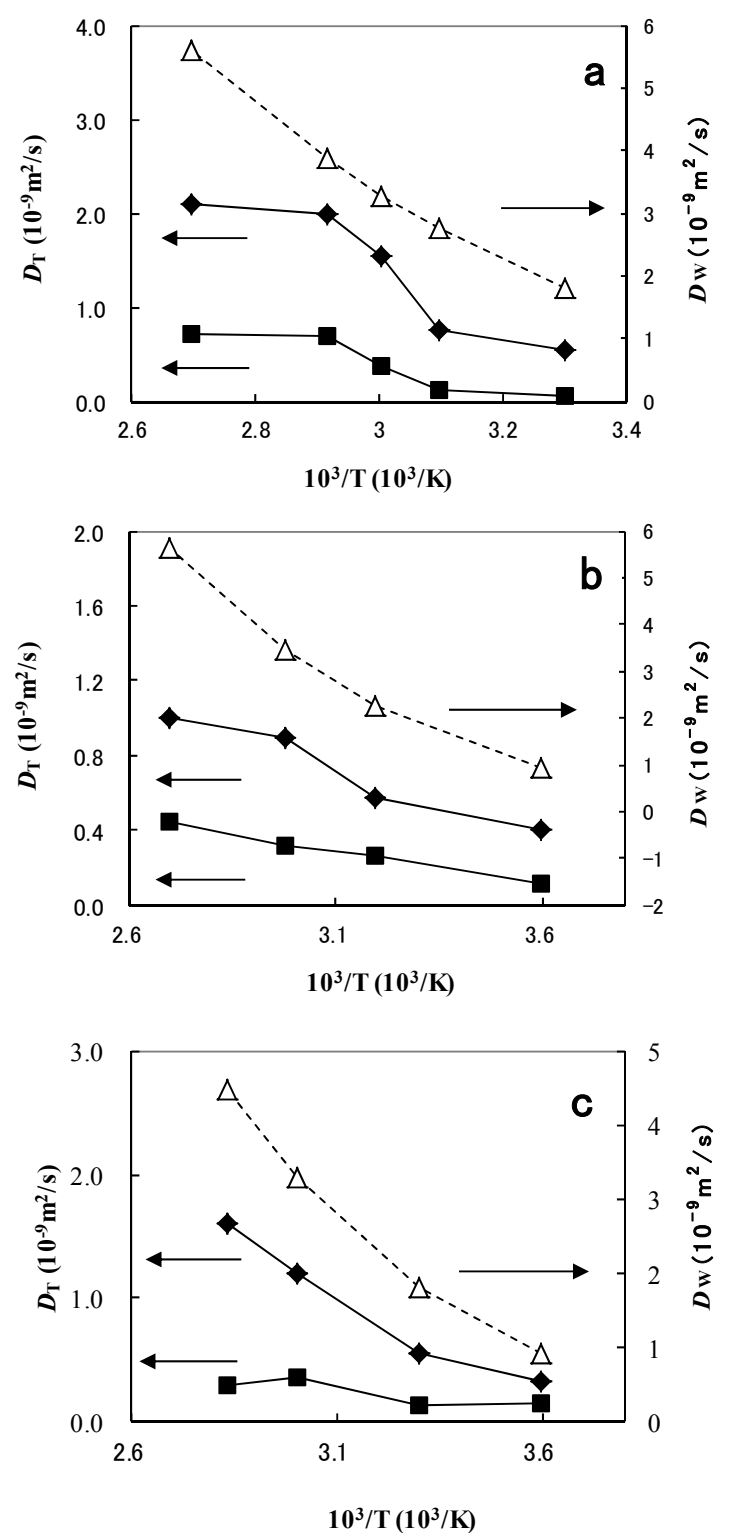

Figure 5. Variations of $D_{\mathrm{T}}$ 's in foodstuffs and $D_{\mathrm{W}}$ with temperature. (a) potato, (b) pork loin, and (c) egg white.

- $D_{\mathrm{T}}(\mathrm{p}) ; \diamond D_{\mathrm{T}}(\mathrm{L}) ; \triangle D_{\mathrm{W}}$

\subsection{Sorption Isotherms of $\mathrm{NaCl}$ in the Potato}

Sorption isotherms of $\mathrm{NaCl}$ by the pre-cooked potato immersed at $30,50,60,70$, and $98^{\circ} \mathrm{C}$ are shown in Figure 6 . The isotherms are very slightly concave upward, which had also been found for the other three foodstuffs. As proposed also for the other foodstuffs (Hashiba et al., 2007, 2008, 2009), the isotherms of $\mathrm{NaCl}$ by the pre-cooked potato are interpreted in terms of Equation (1): the salt is partitioned in liquid water droplets contained in the substrate and is absorbed in the water swollen substrate phase by partition and Langmuir type sorption. The isotherms were reproduced by using the parameters, $\alpha$ and $K_{\mathrm{a}}$ values shown in Table 3. $\beta$ values were assumed to be within the range, $0.16<\beta<0.69$ as the limits of the values estimated from $\varphi_{\mathrm{p}}$ values listed in Table 4. $K_{\mathrm{p}}\left(=\beta K_{\mathrm{p}}\right)$ can be obtained by assuming the parameters, $\beta$ and $K_{\mathrm{p}}$,' where $K_{\mathrm{p}}$, is the partition coefficient of $\mathrm{NaCl}$ in the water swollen substrate. As in the case of the other three foodstuffs, sorption isotherms for the potato are seemingly straight because of the large contribution of the partition in liquid water droplets and of the small one of Langmuir type mode sorption in the water swollen substrate. 

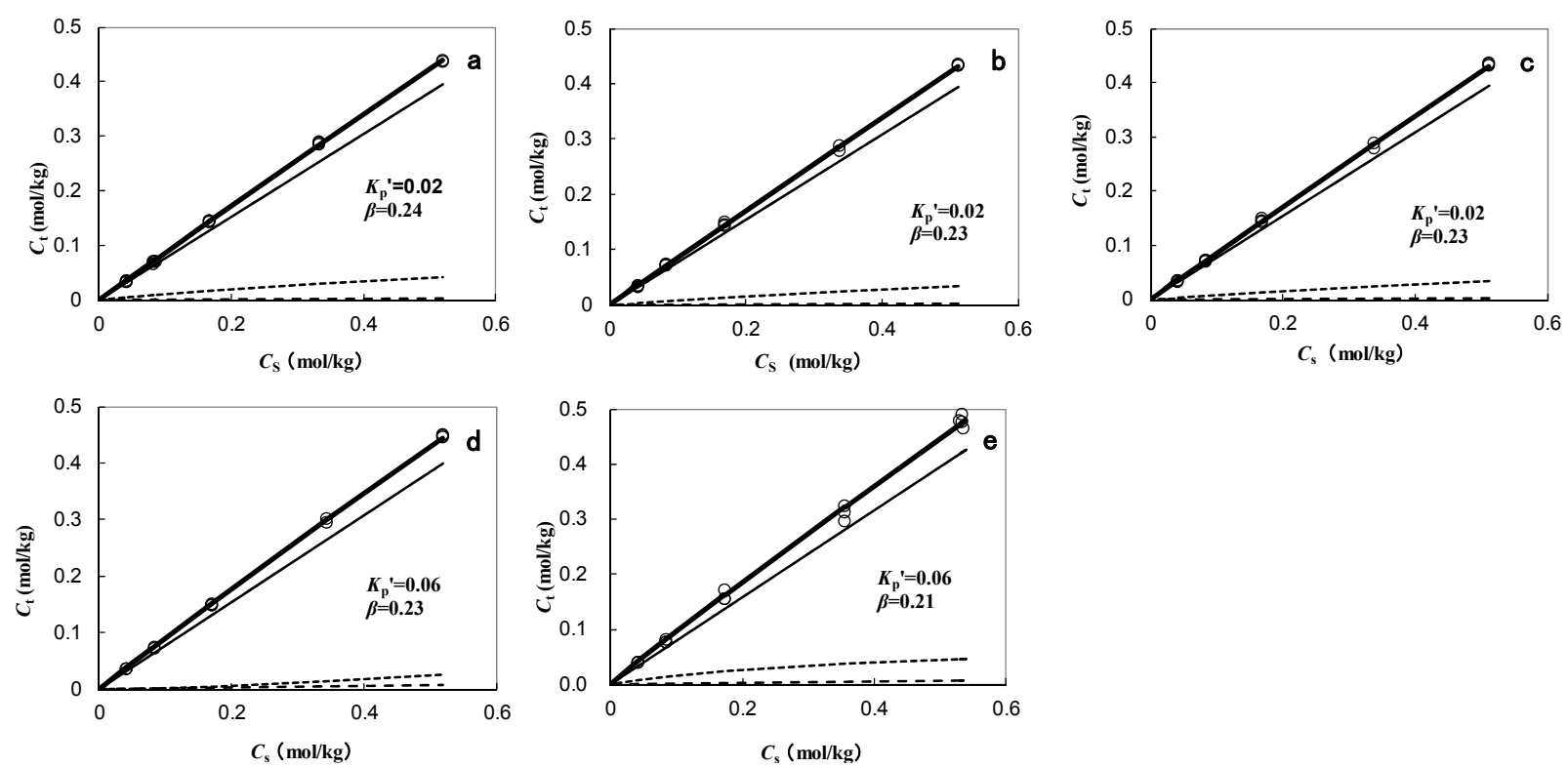

Figure 6. Sorption isotherms of $\mathrm{NaCl}$ by the potato immersed in $\mathrm{NaCl}$ solutions at (a) $30^{\circ} \mathrm{C}$, (b) $50^{\circ} \mathrm{C}$, (c) $60^{\circ} \mathrm{C}$, (d) $70^{\circ} \mathrm{C}$ and (e) $98^{\circ} \mathrm{C} . \bigcirc$ experimental value; calculated $C_{\mathrm{t}}$; $(1-\beta) \mathrm{Cs}$;

$$
\text { ---- } K_{\mathrm{L}} S_{\mathrm{a}} C_{\mathrm{s}} /\left(1+K_{\mathrm{L}} C_{\mathrm{s}}\right) ;-\boldsymbol{-}-K_{\mathrm{p}} C_{\mathrm{s}} \text {. }
$$

\section{Concluding Remarks on the Diffusion of $\mathrm{NaCl}$ in Foodstuffs under Cooking Conditions}

As found for other three foodstuffs, also for pre-cooked potato, we have found dual mode variations of $D$ of $\mathrm{NaCl}$ in their concentration dependences. The water contents of these foodstuffs range from $70 \%$ for pork meat to $95 \%$ for Japanese radish. However, their principal diffusion coefficient, $D_{\mathrm{T}}(\mathrm{L})$, ranges $0.33-2.10 \times 10^{-9} \mathrm{~m} \mathrm{~s}^{-1}$, indicating that the rate determining steps of the diffusion in these foodstuffs are not directly related with the total water contents. We have discussed that the $\mathrm{p}$ and $\mathrm{L}$ regions in these water swollen substrates should be assigned to the regions that determine the diffusion rates. Our observations show the followings; 1 . The $D_{\mathrm{T}}$ 's are in the order of $10^{-9} \mathrm{~m} \mathrm{~s}^{-1}$, which are about 1/2 1/30 of the $D_{\mathrm{W}}$ 's at the corresponding temperatures; 2 . The rapid equilibrium assumed for the $\mathrm{p}$ and $\mathrm{L}$ species may hold not as a mere assumption but as representing a mechanism in the very close regions in the environments provided by some charged macromolecules; 3 . The sorption isotherms of $\mathrm{NaCl}$ by these four foodstuffs show almost linear relations with very slightly concave upward curvatures, in which the Langmuir type sorptions of $\mathrm{NaCl}$ are concealed.

From the present interpretation of the diffusion of $\mathrm{NaCl}$ in potato and other foodstuffs, we may calculate back to the concentration profiles at any cooking temperature and time. Such profiles give the total $\mathrm{NaCl}$ concentrations as well as those of the outer layer in the foodstuffs. These pieces of knowledge may contribute to the $\mathrm{NaCl}$ content and also to regulate the surface saltiness of the foodstuffs for good taste. Such quantification may be useful in reducing the salt contents from the cooked foodstuffs.

\section{Acknowlegements}

We thank the Salt Science Research Foundation (No. 1049) for funding the project entitled "Dual mode diffusion and sorption of $\mathrm{NaCl}$ in carbohydrate foodstuffs", and Grant -in -Aid for Scientific Research C (No. 23500939) from the Japan Society for the Promotion of Science for funding the project "A study on the diffusion of seasoning components in the foodstuffs to make cooked food good-tasting". We greatly thank Japan Electron Optics Laboratory Co. Ltd. for taking natural SEM photos.

\section{References}

Crank, J. (1975). The mathematics of diffusion (2nd ed.). Oxford: Oxford University Press.

Cussler, E. L. (1997). Diffusion (2nd ed.). Cambridge: Cambridge University Press.

Djelveh, G., Gros, J. B., \& Bories, B. (1989). An improvement of the cell diffusion method for the rapid determination of diffusion constants in gels or foods. Journal of Food Science, 54(1), 166-169. 
Food Standards Agency. (2007). FSA nutrient and food based guidelines for UK institutions (revised October 2007). http://www.food.gov.uk/multimedia/pdfs/nutrientinstitution.pdf

Fredriksson H., Silverio, J., Anderson, R., Eliasson, A. C., \& Aman, P. (1998). The influence of amylose and amylopectin characteristics on gelatinization and retrogradation properties of different starches. Carbohydrate Polymers, 35, 119-134. http://dx.doi.org/10.1016/S0144-8617(97)00247-6

Guiheneuf, T. M., Gibbs, S. J., \& Hall, L. D. (1997). Measurement of the inter-diffusion of sodium ions during pork brining by one-dimensional ${ }^{23} \mathrm{Na}$ magnetic resonance imaging (MRI). Journal of Food Engineering, 31, 457-471. http://dx.doi.org/10.1016/S0260-8774(96)00085-4

Hashiba, H., Komiyama, J., Nakanishi, T., \& Gocho, H. (2007). Dual mode diffusion of $\mathrm{NaCl}$ in Japanese radish under cooking conditions. Journal of Food Science, 72(3), C154-C162.

Hashiba, H., Gocho, H., \& Komiyama, J. (2008). Dual mode diffusion and sorption of sodium chloride in pre-cooked egg white. LWT-Food Science and Technology, 41(10), 1978-1986. http://dx.doi.org/10.1016/j.1wt.2007.12.006

Hashiba, H., Gocho, H., \& Komiyama, J. (2009). Dual mode diffusion and sorption of sodium chloride in pork meats under cooking conditions. LWT-Food Science and Technology, 42(6), 1153-1163. http://dx.doi.org/10.1016/j.lwt.2009.02.002

Kalichevsky, M. T., \& Blanshard, J. M. V. (1992). A study of the effect of water on the glass transition of 1:1 mixtures of amylopectin, casein and gluten using DSC and DMTA. Carbohydrate Polymers, 19, 271-278. http://dx.doi.org/10.1016/0144-8617(92)90080-A

Karlsson, M. E., \& Eliasson, A. C. (2003). Gelatinization and retrogradation of potato (Solanum tubersum) starch in situ as assessed by differential scanning calorimetry (DSC). LWT-Food Science and Technology, 36, 735-741. http://dx.doi.org/10.1016/S0023-6438(03)00093-8

Komiyama, J., \& Iijima, T. (1974). Diffusion of monoanionic dyes in Nylon. Journal of Polymer Science: Polymer Physics Edition, 12(8), 1465-1476.

Liu H. (1992). A kinetic study of salt diffusion in potato at high temperature. International Journal of Food Science and Technology, 27, 443-455.

Mackie, J. S., \& Mears, P. (1955). The diffusion of electrolytes in a cation-exchange resin membrane I. Theoretical. Proceedings of the royal society of Edinburgh, A, 232, 498-509.

Matano, C. (1932). On the relation between the diffusion-coefficients and concentrations of solid metals. (The nickel-copper system). Japanese Journal of Physics, 8, 109-113.

Michaeli, I., \& Bejerano, T. (1969). On the absorption of salt by water-insoluble polyacid-polybase interacts. Journal of Polymer Science, Part C, No. 22, 909-915.

Mousia, Z., Fahrhat, I. A., Blachot, J. F., \& Michell, J. R. (2000). Effect of water partitioning on the glass-transition behaviour of phase separated amylopectin-gelatin mixtures. Polymer, 41, 1841-1848. http://dx.doi.org/10.1016/S0032-3861(99)00335-3

National institute of health and nutrition. (2010). Dietary Reference Intakes for Japanese. Retrieved from http://www0.nih.go.jp/eiken/english/research/pdf/dris2010_eng.pdf

Okada, T., \& Patilt, J. M. (1998). Ion uptake by zwitterionic surfaces. Langmuir, 14, 6241-6248.

Pajonk, A. S., Saurel, R., \& Andrieu, J. (2003). Experimental study and modeling of effective $\mathrm{NaCl}$ diffusion coefficients values during Emmental cheese brining. Journal of Food Engineering, 60, 307-313. http://dx.doi.org/10.1016/S0260-8774(03)00052-9

Petropoulos, J. H. (1985). Membranes with non-homogeneous sorption and transport properties. In M. Gordon (Ed.), Advances in polymer science (pp. 109-114). New York, NY: Springer-Verlag.

Resources Council, Science and Technology Agency (RCSTA). (1982). Standard Tables of Food Composition in Japan, 4th Edition.

RCSTA. (2005). Standard Tables of Food Composition in Japan, 5th Revised and Enlarged Edition. Retrieved from http://www.mext.go.jp/b_menu/shingi/gijyutu/gijyutu3/toushin/05031802.htm

Robinson, R. A., \& Stokes, R. H. (1959). Electrolyte Solutions. Footnote of Table 11.1 (p. 289), and Appendix 6.2 (p. 465). London: Butterworths. 
Roos, Y. (1995). Phase transitions in foods. New York, NY: Academic Press.

Rüegg, M., \& Schär, W. (1985). Diffusion of salt in food. Bibliography and data on the diffusion and penetration of sodium chloride and other low molecular weight solutes into foodstuffs, prepared within the frame of the European COST 90bis Project.

Sinn, C. G., Dimola, R., Huin, C., Sel, O., \& Antonietti, M. (2006). Binding of ion pairs onto polymer gels via dehydration entropy: A new mechanism for ion exchange. Macromolecules, 39, 6310-6312.

Tamasula P., \& Kozempel, M. F. (1989). Diffusion coefficients of glucose, potassium, and magnesium in Maine Russet Burbank and Maine Katahdin potatoes from 45 to $90^{\circ} \mathrm{C}$. Journal of Food Science, 54(4), 985-989.

United States Department of Agriculture. (2010). Dietary Guidelines for Americans, 2010. http://www.cnpp.usda.gov/dgas2010-policydocument.htm 